Int. J. Morphol.,

35(1):114-119, 2017.

\title{
Histological Characterization of Sacco's Concentrated Growth Factors Membrane
}

\author{
Caracterización Histológica de la Membrana de los Factores de Crecimiento Concentrados Sacco
}

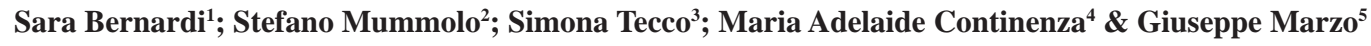

BERNARDI, S.; MUMMOLO, S.; TECCO, S.; CONTINENZA, M. A. \& MARZO, G. Histological characterization of Sacco's concentrated growth factors membrane. Int. J. Morphol., 35(1):114-119, 2017.

SUMMARY: Along with the emerging needs of the dental patients, numerous techniques for oral tissue stimulation and regeneration were developed to be employed in the modern implant rehabilitation therapies. The Concentrated Growth Factors (CGF) are a relatively new therapeutic presidium that can be used for this purpose, enhancing the regenerative potential property of blood cells. Although literature presents numerous studies evaluating the CGF for their clinical uses and efficacy, data regarding their biological characteristics are very few. The present study evaluates and describes the CGF structural morphology by means of classical histological methods, using haematoxilin-eosin and azan mallory stains. A three layers organization with a fibrin complex network was noted, with blood corpuscular elements entrapped, especially in the most external layer. These descriptions enrich the knowledge about this new type of membrane, showing the bio-morphological side of the regenerative techniques. These findings will be useful in clinical practice for the choice of the most suitable technique in each implant rehabilitation.

KEY WORDS: Histology; Guided bone regeneration; Implant dentistry; Concentrated growth factor.

\section{INTRODUCTION}

The tissue regeneration is one of the current therapies proposed when the inflammatory processes end in tissue deficit. In dentistry and maxillofacial surgery, platelets concentrates have been started to be considered as a valid alternative to synthetic or animal membrane during the Guided Bone Regeneration (GBR) intervention. Indeed, because these concentrates are autologous, all the biocompatibility issues are avoided. Furthermore, platelets have been identified as producers of high quantity of growth factors, such as Platelet Derived Growth Factor (PDGF), Transforming Growth Factor-B1(TGF), TGF-B2, Fibroblast Growth Factor (FGF), Vascular Endothelial Growth Factor (VEGF), Insulin-like Growth Factor (IGF) that stimulate cellular proliferation, matrix remodeling and neo-angiogenesis (Dohan Ehrenfest et al., 2010; Farina et al., 2013).

Since various protocols have been developed to obtain these clots, many researchers have questioned their activity in osseous-epithelial regeneration (Soffer et al., 2003; Weibrich et al., 2003a; Weibrich et al., 2003b; Arpornmaeklong et al., 2004; Choi et al., 2004; Pocaterra et al., 2016).

The protocol reported in this study was developed by Sacco in 2006 to obtain a new generation of clots called Concentrated Growth Factors (CGF) (Sacco, 2006). This therapeutic presidium is obtained from blood by a particular device with a special program of centrifugation: acceleration x 30', 2,700 rpm x 2', 2,400 rpm x 4', 2,700 rpm x 4', 3,000 rpm x 3', deceleration x 36" and stop (Sacco).

The different speed of centrifugation produces a big fibrin matrix, with a high density and rich in growth factors as Rodella et al. (2011), reported in their immuno-histochemical study.

Other clinicians reported as CGF seems to be more handful and with more regeneration capability than the other previous presidia (Sohn et al. 2009).

\footnotetext{
${ }^{1}$ Molecular and Ultrastructure Imaging European PhD., Research Assistant, Department Of Life, Health \& Environmental Sciences University of L'Aquila Via Vetoio, Italy.

${ }^{2}$ Periodontology Contract Professor, Dept. of Life, Health \& Environmental Sciences, University of L'Aquila, Italy.

${ }^{3}$ Resercher, University Vita-Salute San Raffaele, Milano.

${ }^{4}$ Anatomy Associate Professor, Dept. of Life, Health \& Environmental Sciences, University of L'Aquila, Italy.

${ }^{5}$ Periodontology Full Professor, Dept. of Life, Health \& Environmental Sciences, University of L'Aquila, Italy.

The study has been conducted in the University of L'Aquila, Italy.
} 
This is one of the principal advantages of CGF: as reported by Anitua et al. (2001), clinically, it is difficult to apply a Platelet Rich Plasma (PRP, the first generation of these compounds) as a mere pellet after the centrifugation of whole blood, because it lacks cohesion, hence it is difficult to maintain the platelet concentrate in the desired surgical site.

As CGF has been developed in 2006, biological data about its properties are not investigated, as well as its histological description.

The aim of this study is to characterize the histological aspects of a CGF membrane.

\section{MATERIAL AND METHOD}

Blood was taken to obtain 2 CGF blocks with the centrifuge device Medifuge ${ }^{\circledR}$, Silfradent s.r.l., (Sofia, Italy) according to the Sacco's procedure (Rodella et al., 2011).
Two clots were cut in situ with a blade, maintaining the major axes horizontal. The samples were fixed in formaldehyde $2 \%$ for the histological procedure (Buys \& Pretorius, 2012).

Then the samples were embedded in paraffin, and then sectioned with a microtome at $5 \mathrm{~mm}$ thickness. The sectioning started maintaining the major axis vertical. The sections were stained with haematoxylin-eosin (HE) and the Azan Mallory (AM) as previously described (Khalili et al. 2012; Dunham \& Schoenlein, 1927). The slides were observed using light microscope (Zeiss, AxioImager A2, Germany) and the images were captured by Leica DFC 320 camera.

\section{RESULTS}

Histological slides highlighted the morphological characteristics of CGF clots. Both the samples stained with HE and AM evidenced membranes composed by three concentric layers (Fig. 1).
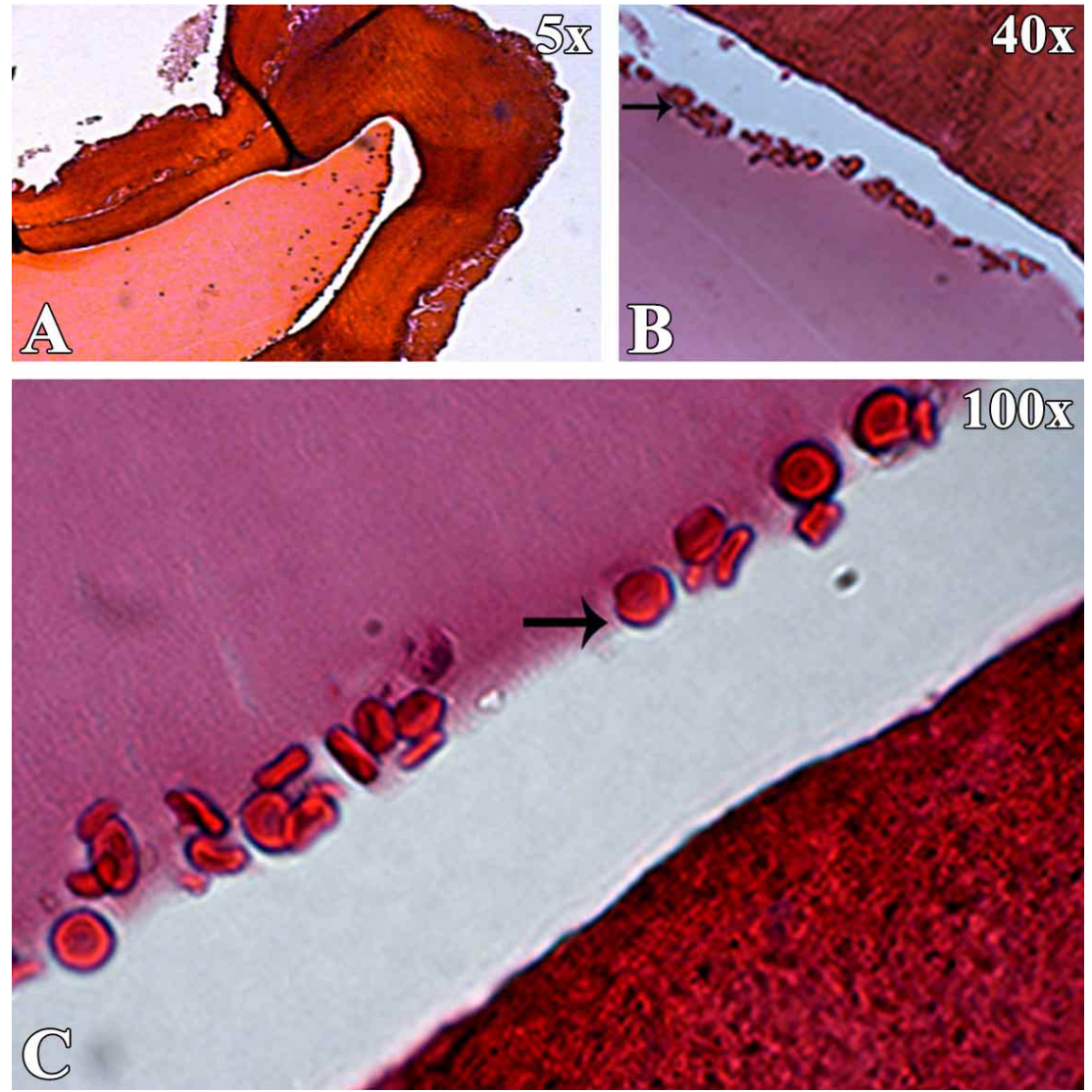

Fig. 1. The CGF clot at 5x (a), 40x (b) and 100x (c) magnification. Three layers are evident and the cells without nucleus placed toward the second layer (HE).
The first layer is characterized by a network of plasmatic proteins containing cells without nucleus, with the typical aspect of erythrocytes. These cells appear placed toward the second layer (Fig. 1).

The second layer appears stained with a high density, for both HE and AM slides, and is the most plentiful (Fig. 2a). Other characteristics are also evident (Fig. 2): AM staining appears more dense and different respect to the third and the first layers; the fibrin network entrappers more cellular elements; there are circular bodies - blue stained - probably collagen fibres, entrapping other corpuscular elements.

The third layer results less coloured in both stains, and is the most interesting.

AM stained sections appears blue coloured, suggesting a collagen fibres deposition; the network appears much larger than those observed in the second layer (Fig. 3a); in addition, there are corpuscular elements in the network, with no nucleus, smaller than red blood cells, such as platelets (Fig. 3b). 

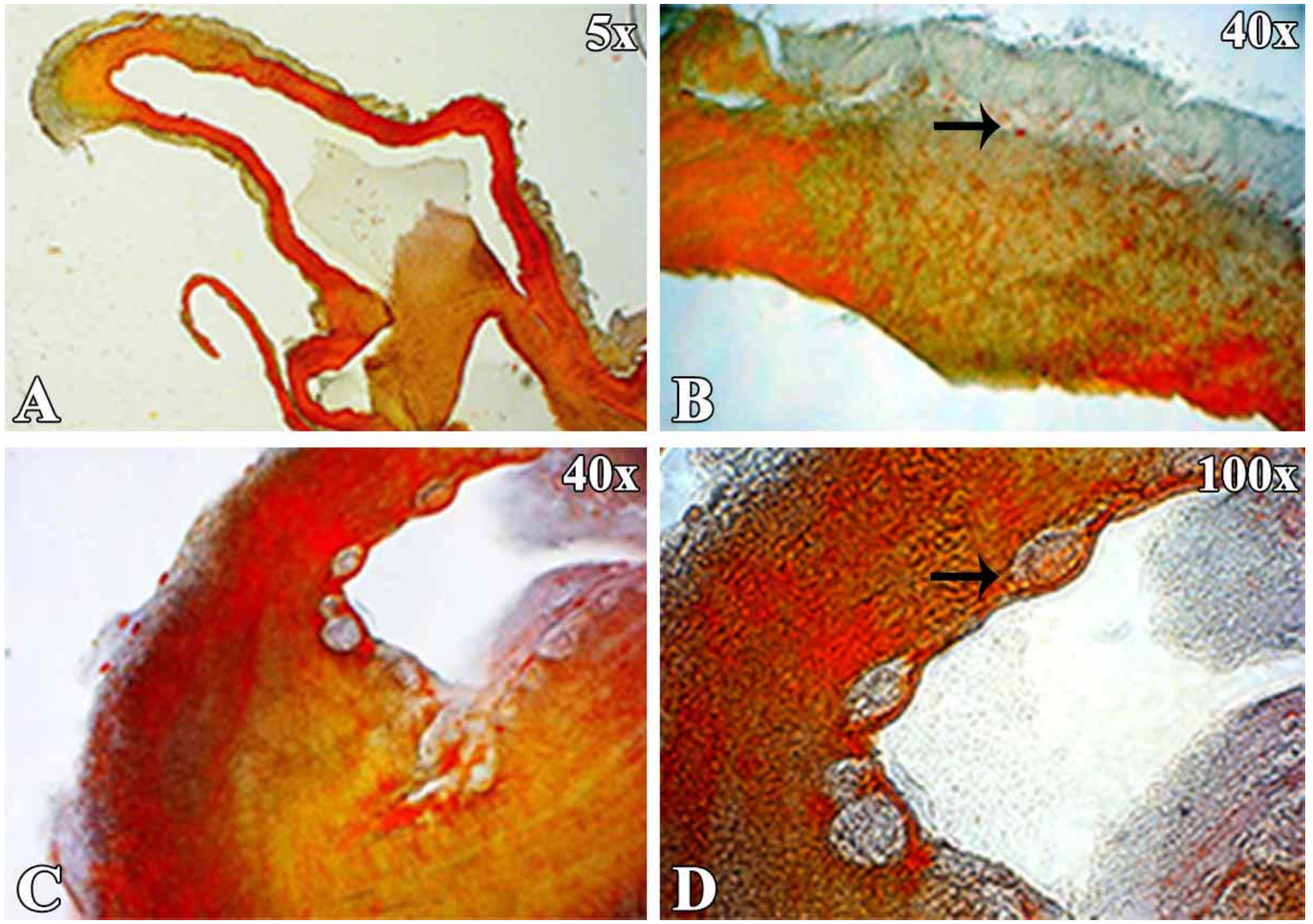

Fig. 2. The CGF clot at 5x, 40x, and 100x magnification. The high density of the second layer (b); cells trapped in the fibrin network (c) and circular bodies blue colored (d) (AM).

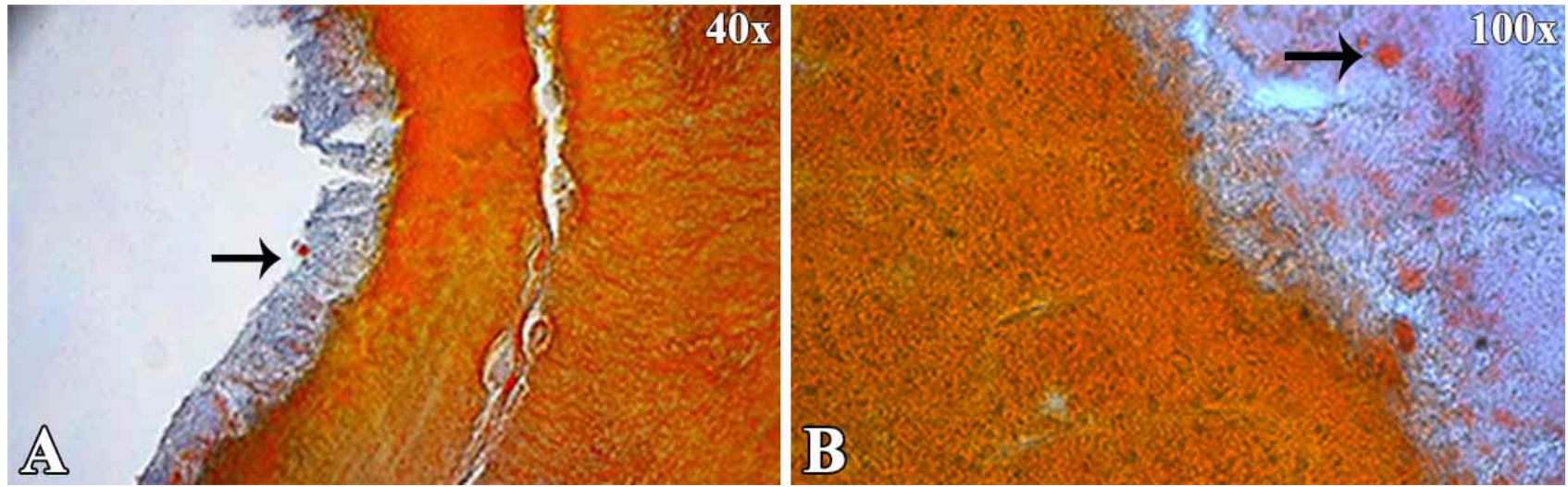

Fig. 3. The third layer at 40x (a) and 100x (b) magnification appears blue colored and with corpuscular elements (AM); to be noticed the particular disposition of fibrin fibers and presence of corpuscular elements.

\section{DISCUSSION}

Recently, many techniques have been developed to produce different types of fibrin matrix with platelets, growth factors and leukocytes.
The CGF can be considered as the new generation of fibrin matrices blocks with a high concentration in growth factors, including platelet-derived growth factor (PDGF), transforming growth factor b (TGF-b), insulin-like growth factor (IGF), epidermal growth factor (EGF), fibroblast growth factor (FGF), and bone morphogenetic protein (BMP) (Rodella et al.). 
PDGF, firstly described by Ross in 1974, is produced by giant cells and stimulates angiogenesis, osteoblastic proliferation, differentiation, and mesenchymal cell division. PDGF also facilitates cell proliferation and collagen synthesis in fibroblast (Bornfeldt et al. 1995).

TGF- $\beta$ are produced by degranulated platelets during the first stages of injuries. It induces the expression of extracellular matrix proteins and affects osteoblasts in an early stage of development and simulates collagen synthesis by fibroblasts, which facilitates regeneration of bone and cartilage, (Ai-Aql et al. 2008).

IGF helps differentiation and stimulates osteogenesis. In particular, IGF I and IGF II stimulate osteoblasts proliferation and differentiated functions such as type I collagen expression, acting as proper paracrine and autocrine regulators (Linkhart et al. 1996).

PDGF and TGF- $\beta$ are especially known to ameliorate tensile strength and callus formation with effects on healing of soft tissue and bone (Cromack et al., 1990; Bolander, 1992; Pierce et al., 1994; Tsay et al. 2005).

Tsay has suggested that growth factors such as PDGF and TGF-b cause chemotaxis of precursor cells of osteoblast to sites where bone regeneration is needed, followed by proliferation and differentiation of osteoblasts (Tsay et al.).

CGF was introduced in 2006 by Sacco; so it is relatively new; for this, its morphological characteristics are not so fully note, compared with Platelet Rich Plasma (PRP) and the Platelet Rich Fibrin (PRF) (Dohan et al., 2006a; Dohan et al., 2006b; Fernández-Barbero et al. 2006; Dohan Ehrenfest et al., 2009).

As the PRP and PRF, the concentric layers disposition is repeated but according to the Rodella study the Growth Factor concentrations seem to be higher.

Researchers mostly focused on its clinical applications, as for example in the sinus lift intervention and ridge augmentation (Tayapongsak et al. 1994; Sohn et al. 2009; Sohn, 2009a; Sohn, 2009b; Sohn et al. 2010 \& Sohn et al. 2011). Very few data are known about its biological and morphological characteristics (Dohan Ehrenfest et al. 2010).

The different centrifugation speeds - used to produce CGF - allow to isolate a matrix of fibrin bigger, thicker and richer in growth factors than the others (Rodella et al.).

The fibrin clot has a high cohesion because of the agglutination of fibrinogen, factor XIII, and thrombin. Factor
XIIIa, activated by thrombin, causes fibrin to clot. This provides protection from plasmin degradation, resulting in higher fibrin tensile strength and stability (Tayapongsak et al.).

From our histological analysis, the primary characteristic of CGF appears to be the fibrin network containing such platelets, leukocytes, and consequently growth factors, able to provide a sort of scaffold for cells migration as fibroblasts and endothelial cells - involved in angiogenesis and tissue remodelling.

Mostly platelets are notable, since they release high concentrations of biologically active proteins to support recruitment, growth and cell morphogenesis (Rodella et al.).

Thus, Sacco's membrane shows a complex three-dimensional architecture which makes it a biomaterial rich in fibrin platelets, leukocytes and growth factors - very suitable both for patient and surgeon (Dohan et al., 2006a; Dohan et al., 2006b; Dohan Ehrenfest et al. 2009).

Because of the particular presence of platelets in peripheral layer, and the particular disposition of fibrin network - histologically evidenced - the use of peripheral layer in tissues regeneration procedures seems advisable. Indeed, platelets are associated to the growth factors, as reported in literature (Grainger et al., 2000; Kusumanto et al., 2003; van der Loos et al. 2010).

Clinical advantages of CGF are better results in terms of time of healing and bone formation, respect to other procedures, as evidenced in many scientific papers (Sohn $e t$ al. 2009; Sohn, 2009a; Sohn, 2009b; Sohn et al., 2011). In particular way, the healing of sinus lift intervention - obtained with CGF membrane - is reached in four months, giving a valid alternative to synthetic bone (Tayapongsak et al.; Sohn, 2009a; Sohn, 2009b; Sohn et al., 2010; Sohn et al., 2011).

Many studies, in addition, reported CGF clots help the wound healing, mostly in diabetic patients affected by problems in healing due to the microangiopathia (Tanaka et al. 2007).

Histology evidenced the morphological characteristics of membranes. Further RCT and metaanalysis are encouraged to explain the effective regenerative potentials of CGF clots and their indications in different regeneration protocols.

ACKNOWLEDGMENTS. The authors acknowledge Dr. Paolo Rasicci and Dr. Silvia Orlando for their contribution to the research. Authors are grateful to Prof. Serena Bianchi for the help in the morphological data discussion. 
BERNARDI, S.; MUMMOLO, S.; TECCO, S.; CONTINENZA, M. A. \& MARZO, G. Caracterización histológica de la membrana de los factores de crecimiento concentrados Sacco. Int. J. Morphol., 35(1):114-119, 2017.

RESUMEN: Junto con las nuevas necesidades dentales de los pacientes, se han desarrollado numerosas técnicas para la estimulación y regeneración de los tejidos orales para ser empleadas en las modernas terapias de rehabilitación de implante. Los Factores de Crecimiento Concentrados (FCC) son relativamente una nueva alternativa terapéutica que pueden utilizarse para este propósito, mejorando la propiedad regenerativa potencial de las células de la sangre. A pesar de que la literatura presenta numerosos estudios que evalúan los FCC por sus usos clínicos y su eficacia, los datos relativos a sus características biológicas son muy escasos. El presente estudio evalúa y describe la morfología estructural de los FCC por medio de métodos histológicos tradicionales, utilizando hematoxilinaeosina y tinción de Azan Mallory. Se observó una organización en tres capas con una compleja red de fibrina, con elementos corpusculares de la sangre atrapados, especialmente en la capa más externa. Estas descripciones enriquecen el conocimiento acerca de este nuevo tipo de membrana, que muestra el lado biomorfológico de las técnicas regenerativas. Estos resultados serán de utilidad en la práctica clínica para la elección de la técnica más adecuada en los casos de rehabilitación con implantes.

PALABRAS CLAVE: Histología; Regeneración ósea guiada; Implantología dental; Factor de crecimiento concentrado.

\section{REFERENCES}

Ai-Aql, Z. S.; Alagl, A. S.; Graves, D. T.; Gerstenfeld, L. C. \& Einhorn, T. A. Molecular mechanisms controlling bone formation during fracture healing and distraction osteogenesis. J. Dent. Res., 87(2):107$18,2008$.

Anitua, E. The use of plasma-rich growth factors (PRGF) in oral surgery. Pract. Proced. Aesthet. Dent., 13(6):487-93, 2001.

Arpornmaeklong, P.; Kochel, M.; Depprich, R.; Kübler, N. R. \& Würzler, $\mathrm{K}$. K. Influence of platelet-rich plasma (PRP) on osteogenic differentiation of rat bone marrow stromal cells. An in vitro study. Int. J. Oral Maxillofac. Surg., 33(1):60-70, 2004.

Bolander, M. E. Regulation of fracture repair by growth factors. Proc. Soc. Exp. Biol. Med., 200(2):165-70, 1992.

Bornfeldt, K. E.; Raines, E. W.; Graves, L. M.; Skinner, M. P.; Krebs, E. G. \& Ross, R. Platelet-derived growth factor. Distinct signal transduction pathways associated with migration versus proliferation. Ann. N. Y. Acad. Sci., (766):416-30, 1995.

Buys, A. V. \& Pretorius, E. Comparing different preparation methods to study human fibrin fibers and platelets using TEM. Microsc. Res. Tech., 75(6):801-6, 2012.

Choi, B. H.; Im, C. J.; Huh, J. Y.; Suh, J. J. \& Lee, S. H. Effect of plateletrich plasma on bone regeneration in autogenous bone graft. Int. J. Oral Maxillofac. Surg., 33(1):56-9, 2004.

Cromack, D. T.; Porras-Reyes, B. \& Mustoe, T. A. Current concepts in wound healing: growth factor and macrophage interaction. J. Trau$m a, 30(12): 129-33,1990$.

Dohan, D. M.; Choukroun, J.; Diss, A.; Dohan, S. L.; Dohan, A. J.; Mouhyi, J. \& Gogly, B. Platelet-rich fibrin (PRF): a second-generation platelet concentrate. Part I: technological concepts and evolution. Oral Surg. Oral Med. Oral Pathol. Oral Radiol. Endod., 101(3):37-44, 2006a.

Dohan, D. M.; Choukroun, J.; Diss, A.; Dohan, S. L.; Dohan, A. J.; Mouhyi, J. \& Gogly, B. Platelet-rich fibrin (PRF): a second-generation platelet concentrate. Part II: platelet-related biologic features. Oral Surg. Oral Med. Oral Pathol. Oral Radiol. Endod., 101(3):45-50, 2006b.

Dohan Ehrenfest, D. M.; de Peppo, G. M.; Doglioli, P. \& Sammartino, G. Slow release of growth factors and thrombospondin-1 in Choukroun's platelet-rich fibrin (PRF): a gold standard to achieve for all surgical platelet concentrates technologies. Growth Factors, 27(1):63-9, 2009.

Dohan Ehrenfest, D. M.; Del Corso, M.; Diss, A.; Mouhyi, J. \& Charrier, J. B. Three-dimensional architecture and cell composition of a
Choukroun's platelet-rich fibrin clot and membrane. J. Periodontol., 81(4):546-55, 2010.

Dunham, H. G. \& Schoenlein, H. W. Stain technology. Biotech. Histochem., 2(1):26, 1927.

Farina, R.; Bressan, E.; Taut, A.; Cucchi, A. \& Trombelli, L. Plasma rich in growth factors in human extraction sockets: a radiographic and histomorphometric study on early bone deposition. Clin. Oral Implants Res., 24(12):1360-8, 2013.

Fernández-Barbero, J. E.; Galindo-Moreno, P.; Avila-Ortiz, G.; Caba, O.; Sánchez-Fernández, E. \& Wang, H. L. Flow cytometric and morphological characterization of platelet-rich plasma gel. Clin. Oral Implants Res., 17(6):687-93, 2006.

Grainger, D. J.; Mosedale, D. E. \& Metcalfe, J. C. TGF-beta in blood: a complex problem. Cytokine Growth Factor Rev., 11(1-2):133-45, 2000.

Khalili, M. A.; Maione, M.; Palmerini, M. G.; Bianchi, S.; Macchiarelli, G. \& Nottola, S. A. Ultrastructure of human mature oocytes after vitrification. Eur. J. Histochem., 56(3):38, 2012.

Kusumanto, Y. H.; Dam, W. A.; Hospers, G. A.; Meijer, C. \& Mulder, N. H. Platelets and granulocytes, in particular the neutrophils, form important compartments for circulating vascular endothelial growth factor. Angiogenesis, 6(4):283-7, 2003.

Linkhart, T. A.; Mohan, S. \& Baylink, D. J. Growth factors for bone growth and repair: IGF, TGF beta and BMP. Bone, 19(1):1-12, 1996.

Pierce, G. F.; Tarpley, J. E.; Allman, R. M.; Goode, P. S.; Serdar, C. M.; Morris, B.; Mustoe, T. A. \& Vande Berg, J. Tissue repair processes in healing chronic pressure ulcers treated with recombinant plateletderived growth factor BB. Am. J. Pathol., 145(6):1399-410, 1994.

Pocaterra, A.; Caruso, S.; Bernardi, S.; Scagnoli, L.; Continenza, M. A. \& Gatto, R. Effectiveness of platelet-rich plasma as an adjunctive material to bone graft: a systematic review and meta-analysis of randomized controlled clinical trials. Int. J. Oral Maxillofac. Surg., 45(8):1027-34, 2016.

Rodella, L. F.; Favero, G.; Boninsegna, R.; Buffoli, B.; Labanca, M.; Scarì, G.; Sacco, L.; Batani, T. \& Rezzani, R. Growth factors, CD34 positive cells, and fibrin network analysis in concentrated growth factors fraction. Microsc. Res. Tech., 74(8):772-7, 2011.

Sacco, L. Lecture. In: International Academy of Implant Prosthesis and Osteoconnection, April 12th 2006.

Soffer, E.; Ouhayoun, J. P. \& Anagnostou, F. Fibrin sealants and platelet preparations in bone and periodontal healing. Oral Surg. Oral Med. Oral Pathol. Oral Radiol. Endod., 95(5):521-8, 2003. 
Sohn, D. S.; Moon, J. W.; Moon, K. N.; Cho, S. C. \& Kang, P. S. New bone formation in the maxillary sinus using only absorbable gelatin sponge. J. Oral Maxillofac. Surg., 68(6):1327-33, 2010.

Sohn, D. S.; Heo, J. U.; Kwak, D. H.; Kim, D. E.; Kim, J. M.; Moon, J. W.; Lee, J. H. \& Park, I. S. Bone regeneration in the maxillary sinus using an autologous fibrin-rich block with concentrated growth factors alone. Implant Dent., 20(5):389-95, 2011.

Sohn, D. S.; Moon, J. W.; Moon, Y. S.; Park, J. S. \& Jung, H. S. The use of concentrated growth factors (CGF) for sinus augmentation. Implant J. (Japan), (38):25-35, 2009.

Sohn, D. S. The effect of concentrated growth factors on ridge augmentation. Dental Inc., Sep/Oct:34-40, 2009a.

Sohn, D. S. The use of concentrated growth factors as alternative to bone substitutes for sinus augmentation. Dental Inc., Mar/Apr:2-7, 2009 b.

Tanaka, R.; Ichioka, S.; Sekiya, N.; Ohura, N.; Uchino, S.; Ojima, A.; Itoh, Y.; Ishihara, O.; Nakatsuka, T. \& Ikebuchi, K. Elastic plasma protein film blended with platelet releasate accelerates healing of diabetic mouse skin wounds. Vox Sang., 93(1):49-56, 2007.

Tayapongsak, P.; O'Brien, D. A.; Monteiro, C. B. \& Arceo-Diaz, L. Y. Autologous fibrin adhesive in mandibular reconstruction with particulate cancellous bone and marrow. J. Oral Maxillofac. Surg., 52(2):161-5, 1994.

Tsay, R. C.; Vo, J.; Burke, A.; Eisig, S. B.; Lu, H. H. \& Landesberg, R. Differential growth factor retention by platelet-rich plasma composites. J. Oral Maxillofac. Surg., 63(4):521-8, 2005.

van der Loos, C. M.; Meijer-Jorna, L. B.; Broekmans, M. E.; Ploegmakers, H. P.; Teeling, P.; de Boer, O. J. \& van der Wal, A. C. Anti-human vascular endothelial growth factor (VEGF) antibody selection for immunohistochemical staining of proliferating blood vessels. $J$. Histochem. Cytochem., 58(2):109-18, 2010.

Weibrich, G.; Kleis, W. K.; Buch, R.; Hitzler, W. E. \& Hafner, G. The Harvest Smart PRePTM system versus the Friadent-Schütze plateletrich plasma kit. Clin. Oral Implants Res., 14(2):233-9, 2003 a.

Weibrich, G.; Kleis, W. K.; Hafner, G.; Hitzler, W. E. \& Wagner, W. Comparison of platelet, leukocyte, and growth factor levels in pointof-care platelet-enriched plasma, prepared using a modified Curasan kit, with preparations received from a local blood bank. Clin. Oral Implants Res., 14(3):357-62, 2003b.
Corresponding author:

Sara Bernardi, D.D.S.

Molecular and Ultrastructure Imaging European PhD

Department Of Life, Health and Environmental Sciences

University of L'Aquila

Via Vetoio, Coppito 2, 67100

L'Aquila

ITALY

Mobile phone +393479801726

Email: sara.bernardi@graduate.univaq.it

Received: 06-10-2016

Accepted: 23-12-2016 